\title{
Transition-metal-free cross-coupling of indium organometallics with chromene and isochroman acetals mediated by $\mathrm{BF}_{3} \cdot \mathrm{OEt}_{2}$
}

\author{
José M. Gil-Negrete, José Pérez Sestelo* and Luis A. Sarandeses ${ }^{\dagger}$ \\ Centro de Investigaciones Científicas Avanzadas (CICA) and Departamento de Química Fundamental, \\ Universidade da Coruña, E-15071 A Coruña, Spain
}

This document is the Accepted Manuscript version of a Published Work that appeared in final form in Organic Letters, copyright (C) American Chemical Society after peer review and technical editing by the publisher.

Organic Letters, volume 18, issue 17, pages 4316-4319, 2 September 2016

Received 14 July 2016, published online 17 August 2016, published in print 2 September 2016

\section{How to cite:}

Transition-Metal-Free Cross-Coupling of Indium Organometallics with Chromene and Isochroman Acetals Mediated by $\mathrm{BF}_{3} \cdot \mathrm{OEt}_{2}$. José M. Gil-Negrete, José Pérez Sestelo, and Luis A. Sarandeses. Organic Letters 201618 (17), 4316-4319. DOI: 10.1021/acs.orglett.6b02058.

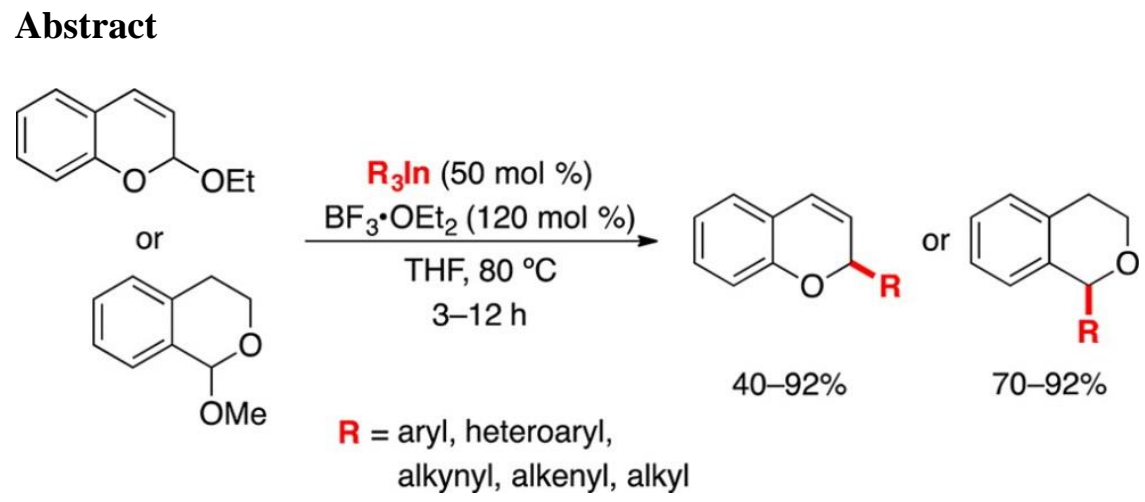

A transition-metal-free coupling of triorganoindium reagents with benzopyranyl acetals mediated by a Lewis acid has been developed. The reaction of $\mathrm{R}_{3} \mathrm{In}$ with chromene and isochroman acetals in the presence of $\mathrm{BF}_{3} \cdot \mathrm{OEt}_{2}$ afforded 2-substituted chromenes and 1substituted isochromans, respectively, in good yields. The reactions proceed with a variety of triorganoindium reagents (aryl, heteroaryl, alkynyl, alkenyl, alkyl) using only $50 \mathrm{~mol} \%$ of the organometallic, thus demonstrating the efficiency of these species. Preliminary mechanistic studies indicate the formation of an oxocarbenium ion intermediate in the presence of the Lewis acid.

Keywords: indium organometallics; carbon-carbon bond forming reactions; transition-metal-free reactions

$\alpha$-Substituted oxygen heterocycles comprise an important structural motif in chemistry, biology, and medicine. ${ }^{1}$ In particular, benzopyrans such as $2 H$-chromene and isochroman with $\alpha$-functional groups constitute a large family of natural and synthetic products with interesting biological activities. For example, iclaprim is an antibiotic in phase III clinical trials for the treatment of hospital-acquired pneumonia $;{ }^{2}$ acolbifene is employed in the treatment of breast cancer; ${ }^{3}$ sonepiprazole is an isochroman analog with activity as a selective dopamine receptor antagonist that has also been investigated as an antipsychotic, ${ }^{4}$ and penidicitrinin $\mathrm{B}$ is a natural product with antioxidant activity. ${ }^{5}$ Additionally, other analogs with these heterocyclic nuclei have found applications as photochromic materials and as precursors 
of flavylium dyes (Figure 1). ${ }^{6}$ Therefore, the development of efficient methods for the synthesis of $\alpha$ substituted benzopyrans such as $2 \mathrm{H}$-chromene and isochroman is of great interest. ${ }^{7}$<smiles>COc1cc(Cc2cnc(N)nc2N)c2c(c1OC)O[C@H](C1CC1)C=C2</smiles><smiles>CC1=C(c2ccc(O)cc2)[C@H](c2ccc(OCCN3CCCCC3)cc2)Oc2ccccc21</smiles>

Acolbifene<smiles>NS(=O)(=O)c1ccc(N2CCN(CC[C@H]3OCCc4ccccc43)CC2)cc1</smiles>

Sonepiprazole<smiles>C1=C[C@H](c2ccccc2)Oc2ccc3ccccc3c21</smiles>

Photochromic material<smiles>Cc1c(C(C)C(C)O)cc(O)c([C@@H]2OC(C)C(C)c3c(C)c(O)cc(O)c32)c1O</smiles>

\section{Penidicitrinin B}

Figure 1. Representative $\alpha$-substituted chromenes and isochromans.

The synthesis of $\alpha$-substituted benzopyrans and $\alpha$-substituted ethers in general can be achieved by nucleophilic addition to an in situ generated oxocarbenium ion formed by the reaction between acetals and Brønsted acids, ${ }^{8}$ Lewis acids, ${ }^{9}$ or under transition metal catalysis. ${ }^{10}$ The oxocarbenium ions play an important role in the synthesis of natural products and bioactive molecules and, in particular, in the chemistry of carbohydrates and polycyclic ethers. ${ }^{11}$ Furthermore, in recent years the oxidative $\alpha$-functionalization of ethers has also been developed. ${ }^{12}$ The nucleophilic counterpart in the addition to oxocarbenium ions is usually a soft nucleophile: e.g., enolates and derivatives, ${ }^{13}$ active methylene compounds, ${ }^{14}$ electron-rich alkenes and arenes, ${ }^{15}$ and alkynes under metal catalysis. ${ }^{16}$ Organometallic species have found limited applications in these reactions due to the low compatibility with the reaction conditions, and mainly organoboron derivatives have been used in this respect. ${ }^{17,18}$ In addition, transition-metal-free coupling reactions of organometallic species have attracted great interest recently due to the drawbacks associated with the use of palladium or nickel in coupling reactions, such as the toxicity, cost, and ligand design. ${ }^{19}$

The applications of indium in organic synthesis have increased steadily in the past few years. ${ }^{20}$ Among these applications, we discovered transition-metal-catalyzed cross-coupling reactions using organoindium reagents. ${ }^{21,22}$ The high efficiency, versatility, and selectivity of these reagents make them useful alternatives to other organometallics in coupling reactions. In addition, the soft nucleophilicity of organoindium reagents and the ongoing interest in novel methods led us to explore the application of these compounds in the 
reaction with acetals in the presence of Lewis acids. In this communication we report a novel transitionmetal-free coupling reaction of triorganoindium reagents with oxocarbenium ion precursors.

Our study started with an assessment of the reaction of an organoindium compound with an acetal in the presence of a Lewis acid. The paramount importance of $\alpha$-arylated benzopyrans led us to start by investigating the reaction of triphenylindium with 2-ethoxy-2H-chromene $(\mathbf{1}$, Table 1$)$ in the presence of different Lewis acids and solvents. The chromene $\mathbf{1}$ was chosen based on its stability and ease of preparation. Other leaving groups different to the alkoxide, such as the acetate, were not considered since they have not been reported in the chemistry of chromenes. Since triorganoindium compounds are normally prepared from the corresponding organolithium reagents by transmetalation with $\mathrm{InCl}_{3}$ in THF solution, and to avoid an evaporation step that could lead to decomposition of the organometallic, ${ }^{23}$ the use of this solvent in the coupling reactions is preferred (or as cosolvent). These considerations prompted us to start our study by testing $\mathrm{BF}_{3} \cdot \mathrm{OEt}_{2}$ as the Lewis acid in the reactions. Initial experiments on the reaction of 1 with $\mathrm{Ph}_{3} \mathrm{In}(100$ mol \%) and $\mathrm{BF}_{3} \cdot \mathrm{OEt}_{2}(200 \mathrm{~mol} \%)$ in DCE/THF (1:1) at $\mathrm{rt}$ afforded the coupling product 2 in an excellent 92\% yield (Table 1, entry 1). Further experiments were performed to reduce the amount of Lewis acid needed and to check the possibility of the indium reagent transferring more than one aryl group in the reaction, as occurs in the transition-metal-catalyzed coupling reactions of these reagents. ${ }^{20}$ In this way the reaction with $40 \mathrm{~mol} \%$ of $\mathrm{Ph}_{3} \mathrm{In}$ and $120 \mathrm{~mol} \%$ of $\mathrm{BF}_{3} \cdot \mathrm{OEt}_{2}$ in THF at $0{ }^{\circ} \mathrm{C}$ afforded 2 in $56 \%$ yield (entry 2). When the reaction was performed at $80{ }^{\circ} \mathrm{C}$, the yield increased to $65 \%$ while the use of $50 \mathrm{~mol} \%$ of $\mathrm{Ph}_{3}$ In led to an excellent 91\% yield (entries 3 and 4, respectively). Furthermore, the use of lower quantities of $\mathrm{BF}_{3} \cdot \mathrm{OEt}_{2}(20 \mathrm{~mol} \%)$ gave a lower yield (entry 5), and finally, the use of other Lewis acids [Cu(OTf) TMSOTf, $\mathrm{Yb}(\mathrm{OTf})_{3}, \mathrm{InBr}_{3}$ ] proved to be ineffective for the production of $\mathbf{2}$ in good yields (entries 6-9), probably due to the incompatibility of THF as a solvent because it is a donor compound that deactivates the acid character of the salt.

Table 1. Reaction Optimization.

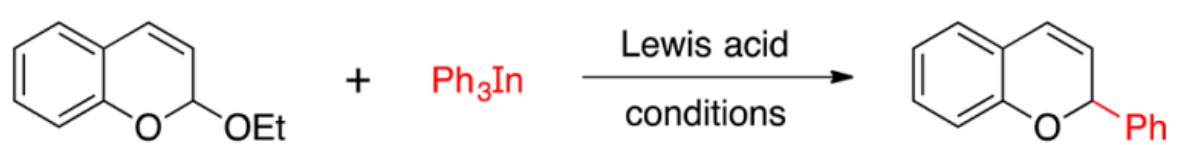

1

2

\begin{tabular}{ccllc}
\hline entry & $\mathrm{mol} \%$ of $\mathrm{Ph}_{3} \mathrm{In}$ & \multicolumn{1}{c}{ Lewis acid $(\mathrm{mol} \%)$} & \multicolumn{1}{c}{ conditions } & yield $(\%)^{a}$ \\
\hline 1 & 100 & $\mathrm{BF}_{3} \cdot \mathrm{OEt}_{2}(200)$ & $\mathrm{DCE} / \mathrm{THF}(1: 1), \mathrm{rt}$ & 92 \\
2 & 40 & $\mathrm{BF}_{3} \cdot \mathrm{OEt}_{2}(120)$ & $\mathrm{THF}, 0{ }^{\circ} \mathrm{C}$ & 56 \\
3 & 40 & $\mathrm{BF}_{3} \cdot \mathrm{OEt}_{2}(120)$ & $\mathrm{THF}, 80^{\circ} \mathrm{C}$ & 65 \\
4 & 50 & $\mathrm{BF}_{3} \cdot \mathrm{OEt}_{2}(120)$ & $\mathrm{THF}, 80^{\circ} \mathrm{C}$ & 91 \\
5 & 50 & $\mathrm{BF}_{3} \cdot \mathrm{OEt}_{2}(20)$ & $\mathrm{THF}, 80^{\circ} \mathrm{C}$ & 10 \\
6 & 50 & $\mathrm{Cu}(\mathrm{OTf})_{2}(120)$ & $\mathrm{THF}, 80^{\circ} \mathrm{C}$ & - \\
7 & 50 & $\mathrm{TMSOTf}(120)$ & $\mathrm{THF}, 80^{\circ} \mathrm{C}$ & - \\
8 & 50 & ${\mathrm{Yb}(\mathrm{OTf})_{3}(120)}_{\mathrm{THF}, 80{ }^{\circ} \mathrm{C}}$ & 33 \\
9 & 50 & $\mathrm{InBr}_{3}(120)$ & $\mathrm{THF}, 80^{\circ} \mathrm{C}$ & 6 \\
\hline
\end{tabular}

${ }^{a}$ Isolated yields. 
Encouraged by these results, we evaluated the scope of this reaction by employing different triorganoindium reagents under the optimized reaction conditions (Scheme 1). In general, reactions of 1 with triarylindium reagents afforded good yields of the corresponding 2-aryl chromenes 2-6 (67-91\%). These reactions proceeded efficiently overnight at $80{ }^{\circ} \mathrm{C}$ except for the reactions with electron-rich arylindium reagents, such tri(4-methoxyphenyl)indium and tri( $p$-tolyl)indium, which took place at room temperature with high yields. Additionally, heteroarylindium compounds such as tri(2- thienyl)indium also reacted efficiently with 1 to give compound 7 in $74 \%$ yield.

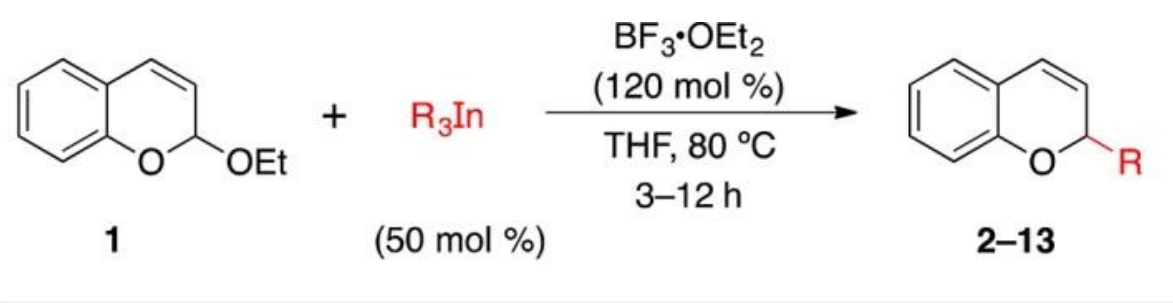<smiles>Cc1ccc(C2C=Cc3ccccc3O2)cc1</smiles><smiles>COc1ccc(C2C=Cc3ccccc3O2)cc1</smiles>

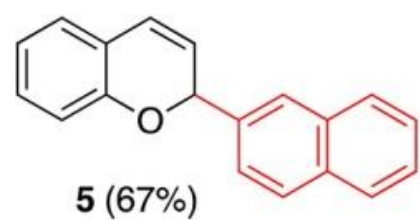<smiles>Fc1ccc(C2C=Cc3ccccc3O2)cc1</smiles><smiles></smiles><smiles>CC(C)(C)[Mg]</smiles><smiles>C(#CC1C=Cc2ccccc2O1)c1ccccc1</smiles><smiles>C1=CC(/C=C/c2ccccc2)Oc2ccccc21</smiles>
$10(92 \%)$

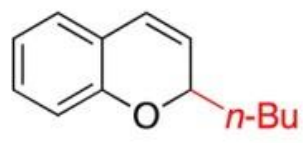

$11(42 \%)^{b}$<smiles>CC1C=Cc2ccccc2O1</smiles>

$12(40 \%)^{c}$<smiles>C1=CC(C2CC2)Oc2ccccc21</smiles>

$13(84 \%)$

${ }^{a}$ Reactions performed at room temperature.

${ }^{b}$ Major regioisomer isolated; $65 \%$ overall yield, ratio C-2/C-4 $=65: 35$.

${ }^{c}$ Major regioisomer isolated; $65 \%$ overall yield, ratio C-2/C-4 $=62: 38$.

Scheme 1. Scope of the $\mathrm{BF}_{3}$-Mediated Reaction of Triorganoindium Reagents with Chromene Acetal 1.

When the reaction was performed with trialkynylindium reagents, the desired 2-alkynyl chromenes 8 and 9 were obtained in good yields ( $85 \%$ and $89 \%$, respectively). The alkynylation of acetals is a key approach to deliver $\alpha$-carbon substituents to oxygenated functional groups due to the possibility of further elaboration of the triple bond to a range of substituents. ${ }^{9 b, 16,24}$ The results obtained in this study demonstrate the utility of indium reagents in the alkynylation of acetals in the presence of Lewis acids. Groups other than aryl and 
alkynyl were also studied to demonstrate the versatility of indium reagents in these reactions. In this sense, the reaction of $\mathbf{1}$ with an alkenylindium compound afforded 2-alkenyl chromene $\mathbf{1 0}$ in an excellent $92 \%$ yield without isomerization. Finally, the reaction of $\mathbf{1}$ with tributyl- and trimethylindium gave lower yields of the products and a lack of regioselectivity, with 2-substituted chromenes $\mathbf{1 1}$ and $\mathbf{1 2}$ obtained along with the 4substituted isomers (65\% yield, ratio C-2/C-4 65:35 to 62:38). Interestingly, the reaction involving tricyclopropylindium afforded the 2-substituted chromene 13 regioselectively in $84 \%$ yield, a result that contrasts with those obtained with the other alkylindium reagents, and thus demonstrating the special reactivity of the cyclopropyl derivatives. Remarkably, all of these reactions give good yields on using $50 \mathrm{~mol}$ $\%$ of the organoindium reagent, which indicates that the triorganoindium reagents transfer more than one group attached to the metal. Nevertheless, when these reactions were performed with $100 \mathrm{~mol} \%$ of $\mathrm{R}_{3} \mathrm{In}$, good yields of the products were obtained even at room temperature, a fact that could indicate that the transfer to the electrophile of the first group attached to the metal is faster than the others.

Once the reaction of $\mathrm{R}_{3} \mathrm{In}$ with chromene acetals in the presence of $\mathrm{BF}_{3} \cdot \mathrm{OEt}_{2}$ was probed, we turned our attention to the study of the reactivity of isochroman derivatives. Isochroman is a relevant structural motif in natural products and biologically active compounds, as well as being a building block in synthetic organic chemistry. ${ }^{1 b}$ Since reactions of chromene acetals are expected to proceed through an oxocarbenium ion intermediate, the use of isochroman acetals as the starting electrophiles should give rise to the same type of intermediate.

Reaction of 1-methoxyisochroman (14, Scheme 2) with $\mathrm{Ph}_{3} \mathrm{In}(50 \mathrm{~mol} \%)$ under the previously described conditions $\left(120 \mathrm{~mol} \%\right.$ of $\mathrm{BF}_{3} \cdot \mathrm{OEt}_{2}$, THF, $\left.80{ }^{\circ} \mathrm{C}\right)$ afforded 1-phenylisochroman (15) in an excellent $92 \%$ yield after $12 \mathrm{~h}$. Compared with the chromene acetal 1, isochroman 14 proved to be slightly less reactive, and it required longer reaction times for the reaction to reach completion, even on using an excess of the indium counterpart. The probable reason for this is that while in $\mathbf{1}$ the formation of the transient oxocarbenium ion is favored by the supplementary stabilization of the double bond at C-3 that gives an aromatic intermediate, in 14 the oxocarbenium ion is only stabilized by the aromatic ring.

The $\mathrm{BF}_{3} \cdot \mathrm{OEt}_{2}$-mediated coupling with isochroman acetal was studied using other organoindium reagents. The reaction with tri(p-tolyl)indium afforded $\mathbf{1 6}$ in $90 \%$ yield, and the coupling with the electron-rich derivative tri(4-methoxyphenyl)indium, under the same conditions, gave isochroman $\mathbf{1 7}$ in $84 \%$ yield. The lower reactivity of isochroman acetal is revealed by the need to heat the reaction mixture under reflux in these two examples, while in the reactions with chromene acetal 1 the reactions with electron-rich $\mathrm{R}_{3}$ In occur at room temperature.

We found that the reaction of $\mathbf{1 4}$ with electron-deficient arylindiums such as tri(4-fluorophenyl)indium also occurs efficiently to afford $\mathbf{1 8}$ in a good $88 \%$ yield (Scheme 2). Heterocyclic nucleophiles such the 2-thienyl ring can also be added to isochroman acetal 14 to obtain 19 in $71 \%$ yield under the optimized conditions. Additionally, 1-alkynyl isochromans were also efficiently prepared by the $\mathrm{BF}_{3} \cdot \mathrm{OEt}_{2}$-mediated addition of trialkynylindium reagents to $14(70-82 \%)$. These results show the utility of indium reagents in the Lewis acid mediated reactions with isochroman acetals and constitute a new entry in the reactivity of these compounds.

Although the mechanism of these reactions was not studied, a plausible proposal could include the generation of an intermediate oxocarbenium ion by reaction between the acetals and the Lewis acid, followed by nucleophilic addition of the triorganoindium reagents. In an attempt to obtain additional information about this process, the chiral chromene acetals 22a and $\mathbf{2 2 b}$ were prepared. ${ }^{25}$ Interestingly, the reaction of $\mathbf{2 2} \mathbf{a}$ or $\mathbf{2 2} \mathbf{b}$, independently, with an excess of $\mathrm{Ph}_{3} \mathrm{In}(100 \mathrm{~mol} \%)$ in the presence of $\mathrm{BF}_{3} \cdot \mathrm{OEt}_{2}$ at room temperature afforded, after $6 \mathrm{~h}$ of reaction, the racemic chromene 2 in good yields (92-94\%) in both cases (Scheme 3). These results are consistent with the formation of an achiral oxocarbenium intermediate 
during the course of the reaction that gives rise to the reaction products by further reaction with the organoindium reagent.

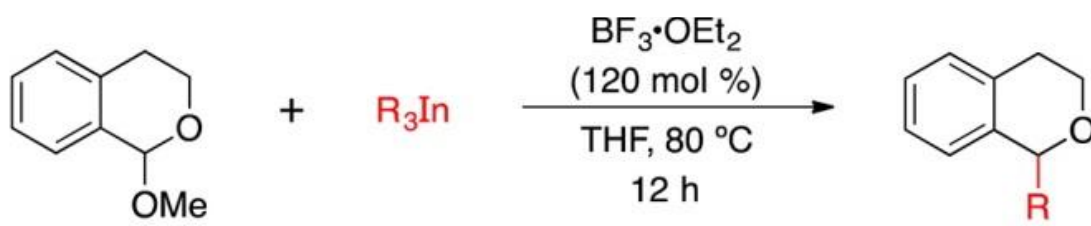

14

(50 mol \%)

15-21<smiles>c1ccc(C2OCCc3ccccc32)cc1</smiles>

15 (92\%)<smiles>Cc1ccc(C2OCCc3ccccc32)cc1</smiles>

16 (90\%)<smiles>COc1ccc(C2OCCc3ccccc32)cc1</smiles><smiles>Fc1ccc(C2OCCc3ccccc32)cc1</smiles>

$18(88 \%)$<smiles>c1csc(C2OCCc3ccccc32)c1</smiles>

$19(71 \%)$<smiles>C(#CC1OCCc2ccccc21)c1ccccc1</smiles>

$20(82 \%)$<smiles>CC#CC1OCCc2ccccc21</smiles>

$21(70 \%)$

Scheme 2. Scope of the $\mathrm{BF}_{3}$-Mediated Reaction of Triorganoindium Reagents with Isochroman Acetal 14.

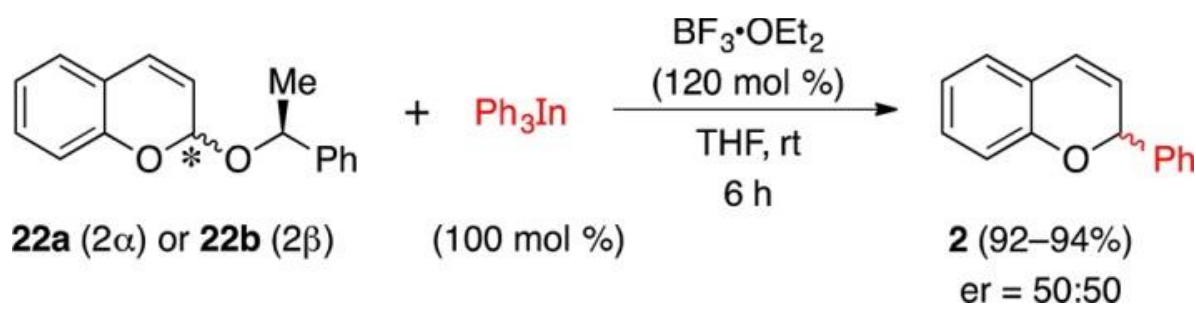

Scheme 3. Results of $\mathrm{BF}_{3}$-Mediated Reaction of Triphenylindium with Chiral Acetals.

In summary, we have developed a new transition-metal-free reaction of organoindium reagents with chromene and isochroman acetals mediated by $\mathrm{BF}_{3} \cdot \mathrm{OEt}_{2}$. The reaction can be performed with a variety of triorganoindium reagents to afford 2-substituted chromenes and 1-substituted isochromans in good yields. These results show the versatility of organoindium reagents in carbon-carbon bond-forming reactions and constitute a new example of the wide synthetic utility of these reagents in addition to their classical reactions under transition metal catalysis. Further studies to expand the synthetic scope of these processes and investigations into the mechanism are in progress and will be reported in due course. 


\section{Associated Content}

\section{Supporting Information}

The Supporting Information is available free of charge on the ACS Publications website at DOI: 10.1021/acs.orglett.6b02058.

- Experimental procedures, compound characterization data, and copies of NMR spectra for all compounds (PDF).

\section{Notes}

The authors declare no competing financial interest.

\section{Acknowledgments}

We are grateful to the Spanish Ministerio de Economía y Competitividad (MINECO, Grant Numbers CTQ2012-31200 and CTQ2015-68369-P) and the EDRF funds for financial support.

\section{References}

(1) (a) Pratap, R.; Ram, V. J. Chem. Rev. 2014, 114, 10476-10526. (b) Markaryan, E. A.; Samodurova, A.

G. Russ. Chem. Rev. 1989, 58, 479-493.

(2) Sorbera, L. A.; Castaner, J.; Rabasseda, X. Drugs Future 2004, 29, 220-225.

(3) Gauthier, S.; Caron, B.; Cloutier, J.; Dory, Y. L.; Favre, A.; Larouche, D.; Mailhot, J.; Ouellet, C.; Schwerdtfeger, A.; Leblanc, G.; Martel, C.; Simard, J.; Mérand, Y.; Bélanger, A.; Labrie, C.; Labrie, F.' J. Med. Chem. 1997, 40, 2117-2122.

(4) TenBrink, R. E.; Bergh, C. L.; Duncan, J. N.; Harris, D. W.; Huff, R. M.; Lahti, R. A.; Lawson, C. F.; Lutzke, B. S.; Martin, I. J.; Rees, S. A.; Schlachter, S. K.; Sih, J. C.; Smith, M. W. J. Med. Chem. 1996, 39, $2435-2437$.

(5) Liu, H.-C.; Du, L.; Zhu, T.-J.; Li, D.-H.; Geng, M.-Y.; Gu, Q.-Q. Helv. Chim. Acta 2010, 93, 2224-2230.

(6) (a) Corns, S. N.; Partington, S. M.; Towns, A. D. Color. Technol. 2009, 125, 249-261. (b) Pina, F.; Melo, M. J.; Laia, C. A. T.; Parola, A. J.; Lima, J. C. Chem. Soc. Rev. 2012, 41, 869-908.

(7) (a) Nicolaou, K. C.; Pfefferkorn, J. A.; Roecker, A. J.; Cao, G. Q.; Barluenga, S.; Mitchell, A. H. J. J. Am. Chem. Soc. 2000, 122, 9939- 9953. (b) Welsch, M. E.; Snyder, S. A.; Stockwell, B. R. Curr. Opin. Chem. Biol. 2010, 14, 347-361.

(8) (a) Reisman, S. E.; Doyle, A. G.; Jacobsen, E. N. J. Am. Chem. Soc. 2008, 130, 7198-7199. (b) Luan, Y.; Qi, Y.; Gao, H.; Ma, Q.; Schaus, S. E. Eur. J. Org. Chem. 2014, 2014, 6868-6872. (c) Luan, Y.; Barbato, K. S.; Moquist, P. N.; Kodama, T.; Schaus, S. E. J. Am. Chem. Soc. 2015, 137, 3233-3236.

(9) (a) Shenoy, S. R.; Woerpel, K. A. Org. Lett. 2005, 7, 1157-1160. (b) Maity, P.; Srinivas, H. D.; Watson, M. P. J. Am. Chem. Soc. 2011, 133, 17142-17145. (c) Rueping, M.; Volla, C. M. R.; Atodiresei, I. Org. Lett. 
2012, 14, 4642-4645. (d) Baxter, M.; Bolshan, Y. Chem. - Eur. J. 2015, 21, 13535-13538. (e) Dasgupta, S.; Rivas, T.; Watson, M. P. Angew. Chem., Int. Ed. 2015, 54, 14154-14158.

(10) (a) Graham, T. J. A.; Doyle, A. G. Org. Lett. 2012, 14, 1616- 1619. (b) Yu, Y.; Yang, W.; Rominger, F.; Hashmi, A. S. K. Angew. Chem., Int. Ed. 2013, 52, 7586-7589.

(11) (a) Nakata, T. Chem. Rev. 2005, 105, 4314-4347. (b) Kang, E. J.; Lee, A. E. Chem. Rev. 2005, 105, 4348-4378.

(12) (a) Park, S. J.; Price, J. R.; Todd, M. H. J. Org. Chem. 2012, 77, 949-955. (b) Wan, M.; Meng, Z.; Lou, H.; Liu, L. Angew. Chem., Int. Ed. 2014, 53, 13845-13849. (c) Chen, W.; Xie, Z.; Zheng, H.; Lou, H.; Liu, L. Org. Lett. 2014, 16, 5988-5991. (d) Muramatsu, W.; Nakano, K. Org. Lett. 2015, 17, 1549-1552. (e) Xiang, M.; Meng, Q.- Y.; Gao, X.-W.; Lei, T.; Chen, B.; Tung, C.-H.; Wu, L.-Z. Org. Chem. Front. 2016, 3, 486-490.

(13) (a) Clausen, D. J.; Floreancig, P. E. J. Org. Chem. 2012, 77, 6574-6582. (b) Liu, X.; Sun, B.; Xie, Z.; Qin, X.; Liu, L.; Lou, H. J. Org. Chem. 2013, 78, 3104-3112. (c) Meng, Z.; Sun, S.; Yuan, H.; Lou, H.; Liu, L. Angew. Chem., Int. Ed. 2014, 53, 543-547.

(14) (a) Xiang, M.; Meng, Q.-Y.; Li, J.-X.; Zheng, Y.-W.; Ye, C.; Li, Z.-J.; Chen, B.; Tung, C.-H.; Wu, L.-Z. Chem. - Eur. J. 2015, 21, 18080-18084. (b) Li, F.; Meng, Z.; Hua, J.; Li, W.; Lou, H.; Liu, L. Org. Biomol. Chem. 2015, 13, 5710-5715.

(15) (a) Qian, B.; Qiao, C.; Xie, Y.; Huang, H. ChemCatChem 2015, 7, 250-253. (b) Padhi, B.; Reddy, D. S.; Mohapatra, D. K. Eur. J. Org. Chem. 2015, 2015, 542-547.

(16) (a) Michalska, M.; Songis, O.; Taillier, C.; Bew, S. P.; Dalla, V. Adv. Synth. Catal. 2014, 356, 2040-2050. (b) Srinivas, H. D.; Maity, P.; Yap, G. P. A.; Watson, M. P. J. Org. Chem. 2015, 80, 4003-4016. (c) Haidzinskaya, T.; Kerchner, H. A.; Liu, J.; Watson, M. P. Org. Lett. 2015, 17, 3857-3859.

(17) (a) Moquist, P. N.; Kodama, T.; Schaus, S. E. Angew. Chem., Int. Ed. 2010, 49, 7096-7100. (b) Vo, C.V. T.; Mitchell, T. A.; Bode, J. W. J. Am. Chem. Soc. 2011, 133, 14082-14089. (c) Baxter, M.; Bolshan, Y. Chem. - Eur. J. 2015, 21, 13535-13538.

(18) For related reactions using organoindium species in carbohydrate derivatives, see: (a) Price, S.; Edwards, S.; Wu, T.; Minehan, T. Tetrahedron Lett. 2004, 45, 5197-5201. (b) Lubin-Germain, N.; Baltaze, J.-P.; Coste, A.; Hallonet, A.; Lauréano, H.; Legrave, G.; Uziel, J.; Augé, J. Org. Lett. 2008, 10, 725-728.

(19) For a review, see: (a) Sun, C.-L.; Shi, Z.-J. Chem. Rev. 2014, 114, 9219-9280. Other leading references: (b) Chen, Q.; du Jourdin, X. M.; Knochel, P. J. Am. Chem. Soc. 2013, 135, 4958-4961. (c) Chen, Q.; León, T.; Knochel, P. Angew. Chem., Int. Ed. 2014, 53, 8746-8750.

(20) For a review, see: Shen, Z.-L.; Wang, S.-Y.; Chok, Y.-K.; Xu, Y.-H.; Loh, T.-P. Chem. Rev. 2013, 113, 271-401.

(21) Selected references: (a) Pérez, I.; Pérez Sestelo, J.; Sarandeses, L. A. J. Am. Chem. Soc. 2001, 123, 4155-4160. (b) Rodríguez, D.; Pérez Sestelo, J.; Sarandeses, L. A. J. Org. Chem. 2003, 68, 2518-2520. (c) Rodríguez, D.; Pérez Sestelo, J.; Sarandeses, L. A. J. Org. Chem. 2004, 69, 8136-8139. (d) Riveiros, R.; Rodríguez, D.; Pérez Sestelo, J.; Sarandeses, L. A. Org. Lett. 2006, 8, 1403-1406. (e) Caeiro, J.; Pérez Sestelo, J.; Sarandeses, L. A. Chem. - Eur. J. 2008, 14, 741-746. (f) Riveiros, R.; Tato, R.; Pérez Sestelo, J.; Sarandeses, L. A. Eur. J. Org. Chem. 2012, 2012, 3018-3023. For recent contributions, see: (g) PérezCaaveiro, C.; Pérez Sestelo, J.; Martínez, M. M.; Sarandeses, L. A. J. Org. Chem. 2014, 79, 9586-9593. (h) 
Mosquera, Á.; Fernández, M. I.; Canle López, M.; Pérez Sestelo, J.; Sarandeses, L. A. Chem. - Eur. J. 2014, 20, 14524-14530.

(22) Other leading references: (a) Takami, K.; Yorimitsu, H.; Shinokubo, H.; Matsubara, S.; Oshima, K. Org. Lett. 2001, 3, 1997- 1999. (b) Lee, P. H.; Sung, S.-Y.; Lee, K. Org. Lett. 2001, 3, 3201- 3204. (c) Lee, K.; Seomoon, D.; Lee, P. H. Angew. Chem., Int. Ed. 2002, 41, 3901-3903. (d) Lehmann, U.; Awasthi, S.; Minehan, T. Org. Lett. 2003, 5, 2405-2408. (e) Takami, K.; Mikami, S.; Yorimitsu, H.; Shinokubo, H.; Oshima, K. J. Org. Chem. 2003, 68, 6627-6631. (f) Baker, L.; Minehan, T. J. Org. Chem. 2004, 69, 3957-3960. (g) Jin, L.; Zhao, Y.; Zhu, L.; Zhang, H.; Lei, A. Adv. Synth. Catal. 2009, 351, 630-634. (h) Chen, Y.-H.; Sun, M.; Knochel, P. Angew. Chem., Int. Ed. 2009, 48, 2236-2239. (i) Shen, Z.-L.; Goh, K. K. K.; Yang, Y.-S.; Lai, Y.-C.; Wong, C. H. A.; Cheong, H.-L.; Loh, T.-P. Angew. Chem., Int. Ed. 2011, 50, 511-514. (j) Shen, Z.-L.; Lai, Y.-C.; Wong, C. H. A.; Goh, K. K. K.; Yang, Y.-S.; Cheong, H.-L.; Loh, T.-P. Org. Lett. 2011, 13, 422-425. (k) Adak, L.; Yoshikai, N. J. Org. Chem. 2011, 76, 7563- 7568. (1) Bernhardt, S.; Shen, Z.-L.; Knochel, P. Chem. - Eur. J. 2013, 19, 828-833. (m) Lee, D.; Ryu, T.; Park, Y.; Lee, P. H. Org. Lett. 2014, 16, 1144-1147. (n) Thapa, S.; Gurung, S. K.; Dickie, D. A.; Giri, R. Angew. Chem., Int. Ed. 2014, 53, 11620-11624.

(23) Yasuda, M.; Haga, M.; Baba, A. Organometallics 2009, 28, 1998- 2000.

(24) Selected references: (a) Johnson, W. S.; Elliott, R.; Elliott, J. D. J. Am. Chem. Soc. 1983, 105, 2904-2905. (b) Ichikawa, Y.; Isobe, M.; Goto, T. Tetrahedron Lett. 1984, 25, 5049-5052. (c) Granja, J. R.; Castedo, L.; Mouriño, A. J. Org. Chem. 1993, 58, 124-131. (d) Linderman, R. J.; Chen, S. Tetrahedron Lett. 1996, 37, 3819- 3822. (e) Yoshimatsu, M.; Gotoh, S.; Ikeda, K.; Komori, A. M. J. Org. Chem. 1998, 63, 6619-6624. (f) Schneider, U.; Dao, H. T.; Kobayashi, S. Org. Lett. 2010, 12, 2488-2491.

(25) The absolute stereochemistry of diastereomers of 22 was not determined.

\footnotetext{
*sestelo@udc.es

${ }^{\dagger}$ luis.sarandeses@udc.es
} 